\title{
SELECTING A COMPETITIVE STRATEGY FOR MANUFACTURING COMPANY USING THE ANALYTIC HIERARCHY PROCESS
}

\author{
Irina Bondareva ${ }^{1}$, Irina Druzhinina ${ }^{2}$, Róbert Tomčík ${ }^{3}$
}

\begin{abstract}
Sustainable growth of enterprises, as well as their competitiveness enhancement, is based largely on the formation of strategic potential. To ensure fulfillment of objectives on maintaining or strengthening the competitive position of the company, suitable competitive strategy, as a tool of strategic management, should be selected and implemented. However, optimal strategy should also form the strategic potential, i.e. the vision of how a company can use its reserves to increase competitiveness.

The aim of the article was to select an effective competitive strategy from several alternatives with the help of Analytic Hierarchy Process (AHP) method. Company, that is recognized as the leader in the production of radiopharmaceuticals on the Slovak market was an object of this study. Calculations showed that the company should focus on the development of new products and keep the position on the existing markets rather than entering a new one. Based on the chosen strategy, it is also possible to create or customize the investment portfolio of the company, which ensures strengthening its competitive position.
\end{abstract}

JEL Classification Numbers: G11, E22, O12, DOI: http://dx.doi.org/10.12955/cbup.v3.584

Keywords: competitive strategy, investment portfolio, innovations, pairwise comparison, Analytic Hierarchy Process, AHP

\section{Introduction}

The creation of competitive conditions becomes a strategic objective of public authorities in ensuring the competitiveness of the Slovak economy. Although the overall improvement of competitiveness can only be achieved through increased competitiveness at different areas and levels of economy (products and services, individual companies, sectors, regions and countries, etc.), particular importance is given to competitiveness of enterprises, which forms the main pillar of the economy.

Due to the current market conditions, new strategic approaches to solve the problems of increasing the competitiveness are required. Therefore, the effectiveness of any enterprise depends on careful consideration followed by the processing of the competitive strategy, which helps to fully exploit competitive advantages of the company and forms its source potential necessary for company's functioning. In other words, the competitive strategy is one of the elements of a comprehensive management system, representing the summary of management decisions needed for creation and usage of company's competitive advantages. Attention given to strategic planning in leading companies is based on assumption that significant economic effect, not only in coordination process of policy within the internal structures of company, but also in orientation on achieving overall goals of the entire company, depends on effective strategy (Porter, 2005, p. 26).

Innovative methods used for solving strategic management's tasks, as well as forming of strategic potential (i.e. the abilities and possibilities of how a company could use internal and external resources to support its outputs), represent additional options for the development of enterprises and increasing their competitiveness (Kaplan \& Norton, 2006; Fleisher \& Bensoussan, 2005).

Sustainable growth of the company, as well as increasing its competitiveness, largely depends on creating an effective investment portfolio. The investment portfolio of the enterprise consists of a set of investment projects used to ensure a strong competitiveness through selection of the most effective investment possibilities.

\footnotetext{
${ }^{1}$ Assoc. Prof., MSc Irina Bondareva, CSc., Institute of Management, Slovak University of Technology in Bratislava, irina.bondareva@stuba.sk

${ }^{2}$ Prof. Irina Druzhinina, CSc. Institute of Economics and Management, Moscow State University of Design and Technology, irinadrug@mail.ru

3 MSc Róbert Tomčík, Institute of Management, Slovak University of Technology in Bratislava, robert.tomcik@stuba.sk
} 
Unlike other investment options (securities portfolio, portfolio of bank deposits, certificates of deposit, etc.), the investment portfolio of real objects (tangible fixed assets) is generally the most capitalintensive, the least liquid, highly risky, and the most complex in terms of managing. Numerous requirements can be expected for the formation and selection of appropriate investment projects. Nevertheless, the company could not operate without investment into fixed assets.

As previously mentioned, the process of creating a suitable investment portfolio is, thus, associated with the selection of investment opportunities in accordance with the given assumptions (criteria) defined by strategy.

Portfolio analysis is a tool for strategic management. It helps an organizational leadership to identify and evaluate its sources in order to invest them into the most promising directions or, on the other hand, to reduce (or even terminate) investment in inefficient projects.

It is assumed that the investment portfolio should be balanced. Thus, it is necessary to provide proper combination of organizational units that do not provide the inflow of funds (such as Radiation Safety Section, Quality Control Department, etc.) with units which ensure the inflow of funds (e.g. Radiopharmaceutical Manufacture Department, PET Centre Department) within the company (BIONT, 2015a).

The purpose of portfolio analysis is to harmonize business strategies and allocation of resources among the business units of the company. Thus, the ability to logically structure and visually represent strategic issues of the company and the relatively simple presentation of obtained results are considered as the main advantages.

This article analyzes the possibility of using "Analytic Hierarchy Process (AHP)" to select an appropriate competitive strategy for a particular company. Based on the chosen strategy, the effective investment portfolio could be compiled thereafter.

\section{Creating a set of competitive strategies}

The object of this research is the BIONT, a.s. company, which is focused on the area of nuclear medicine with a special focus on Positron Emission Tomography (PET). The company is engaged in:

- production of radiopharmaceuticals,

- nuclear medicine,

- research and development of radionuclides and radiopharmaceuticals,

- distribution of radiopharmaceuticals for PET centers logistically feasible,

- education, training and the dissemination of the company's know-how (BIONT, 2015b).

Although the company is highly competitive, it is necessary to define an advancing movement of business. The company should choose a proper strategy, which will strengthen its competitive position. For the company in the stage of maturity, with a prominent position in the market, the following set of strategies (hereinafter "alternatives") could be offered:

- Reverse Integration is carried out in the direction of control over the material flows. It is oriented toward long cooperation with suppliers who provide inputs at lower prices than the competitors could get. This can be achieved by using an individual approach to each supplier, establishing mutually beneficial terms of delivery, payment, etc.

- Development of business abroad. The company has already begun to implement this strategy. BIONT, a.s. is a contract manufacturer of 18F-Fludeoxyglucose (FDG) for a Radiomedic, s.r.o., Řež, Czech Republic and BSM Diagnostica GmbH, Vienna, Austria. Company's product - "biontFDG" radiopharmaceutical - is already registered in six countries 
of the European Union. It has been manufactured under the license by Eczacıbaş1-Monrol in Romania since 2012. However, the strategy of expanding the radiopharmaceuticals to foreign countries is limited. It results from the narrow time frame of ingestion of the product because of its short half-life (only a few hours). This fact reduces the range of customers within only a few hundred kilometers. Therefore, other factories in Bulgaria and Poland are still in the process of being built (BIONT, 2015b).

- Direct integration is related to acquisition of control over distribution and sales systems. It is necessary to reduce a number of intermediaries between the company and consumers in case of medium and large deliveries.

- New products/same markets (centered or horizontal diversification). It is very important to develop and offer new products (services) before the competitors. In addition to standard PET/CT examination, along with the help of FDG, another examination using 11CMethionine is provided. New radiopharmaceuticals are also under development.

- Same products/new markets. It is necessary to enforce an active marketing policy to enter the new markets, such as participation in exhibitions and competitions, promotion of the company's brand, and enhancement of its value to consumers.

- Same products/same markets. In order to increase the share on existing market, an individual approach to each client is required.

However, objective decision-making process requires assessment of strategies according to several criteria. Evaluation of particular strategies according to each criterion separately does not constitute a complicated process, but if it is necessary to evaluate a set of alternatives, taking into account all the criteria, it is much more problematic.

\section{Selection of the optimal competitive strategy according to specified criteria}

With the help of the Analytic Hierarchy Process (AHP) in accordance with specified criteria, the optimal competitive strategy has been chosen. The procedure is described below.

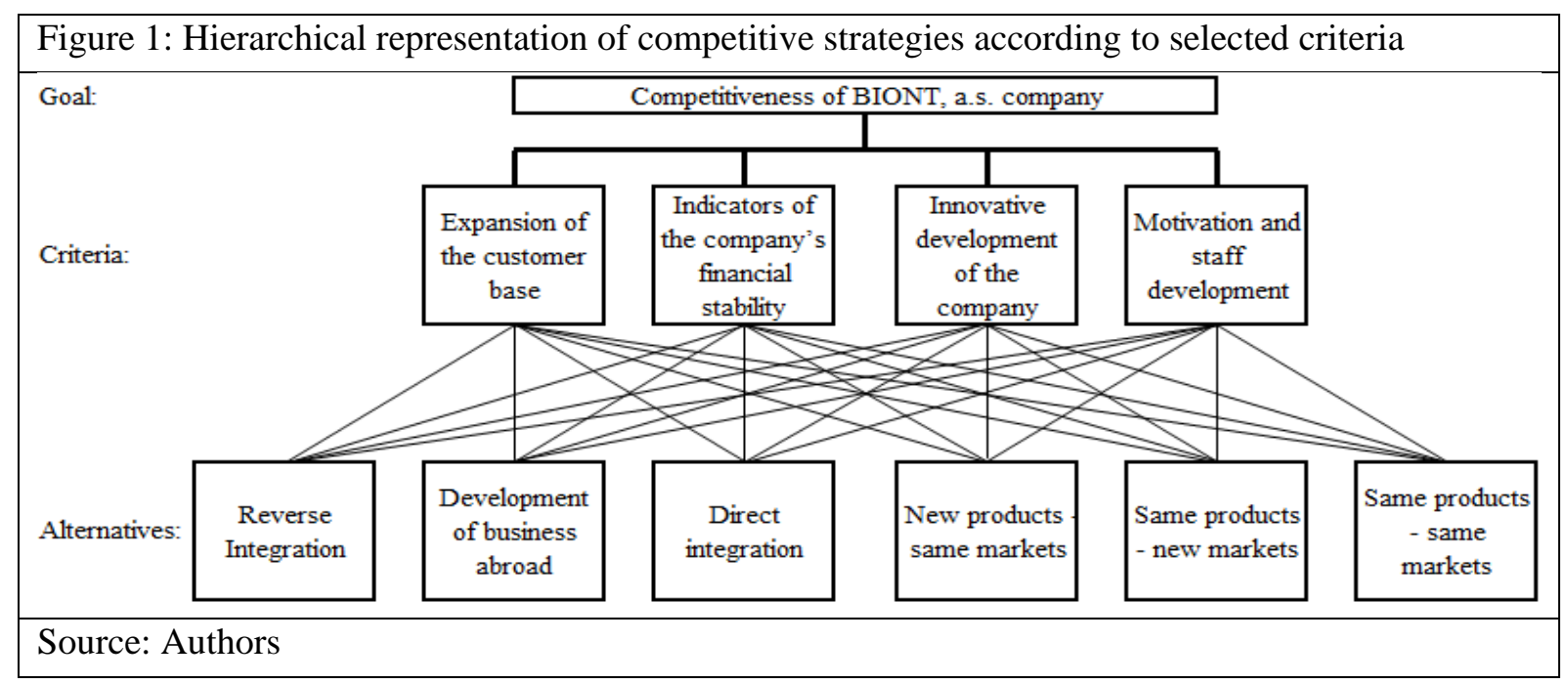

The flexibility of the AHP method, as a multiple-criteria decision-making model, allows us to clearly define the optimal competitive strategy according to specified criteria. The procedure of the AHP method involves justification of selected criteria as well as their evaluation on the basis of the pairwise comparison. Universal Balanced Scorecard, which determines strategic directions of almost any company (Kaplan \& Norton, 2005, p. 20), has been used to choose the criteria:

1. Expansion of the customer base (E), 
2. Indicators of the company's financial stability (F),

3. Innovative development of the company (I),

4. Motivation and staff development (M).

AHP hierarchical representation of competitive strategies, ensuring the growth of competitiveness of the selected company, is depicted in Figure 1.

Pairwise comparison of the criteria is summarized in comparison matrix (Table 1). Each comparison is marked by a number according to Saaty's Rating Scale.

\begin{tabular}{|c|c|c|c|c|}
\hline Table 1: Pairwise comparison of criteria \\
\hline Criteria & $\mathbf{E}$ & $\mathbf{F}$ & $\mathbf{I}$ & $\mathbf{M}$ \\
\hline $\mathbf{E}$ & 1 & $1 / 5$ & $1 / 7$ & $1 / 3$ \\
\hline $\mathbf{F}$ & 5 & 1 & $1 / 3$ & 5 \\
\hline $\mathbf{I}$ & 7 & 3 & 1 & 9 \\
\hline $\mathbf{M}$ & 3 & $1 / 5$ & $1 / 9$ & 1 \\
\hline Total & $\mathbf{1 6 . 0 0}$ & $\mathbf{4 . 4 0}$ & $\mathbf{1 . 5 9}$ & $\mathbf{1 5 . 3 3}$ \\
\hline Source: Authors & &
\end{tabular}

The next step is to normalize the comparison matrix (Table 2).

\begin{tabular}{|c|c|c|c|c|c|c|c|}
\hline \multicolumn{1}{|l|}{ Table 2: Normalized matrix } \\
\hline Criteria & $\mathbf{E}$ & $\mathbf{F}$ & $\mathbf{I}$ & $\mathbf{M}$ & Total & $\begin{array}{c}\text { Eigenvector } \\
\text { (Priority vector) }\end{array}$ & $\begin{array}{c}\text { Consistency } \\
\text { Measurement }\end{array}$ \\
\hline $\mathbf{E}$ & 0.063 & 0.045 & 0.090 & 0.022 & 0.220 & 0.055 & 4.057 \\
\hline $\mathbf{F}$ & 0.313 & 0.227 & 0.210 & 0.326 & 1.076 & 0.269 & 4.456 \\
\hline $\mathbf{I}$ & 0.438 & 0.682 & 0.630 & 0.587 & 2.336 & 0.584 & 4.458 \\
\hline $\mathbf{M}$ & 0.188 & 0.045 & 0.070 & 0.065 & 0.368 & 0.092 & 4.080 \\
\hline Total & $\mathbf{1 . 0 0 0}$ & $\mathbf{1 . 0 0 0}$ & $\mathbf{1 . 0 0 0}$ & $\mathbf{1 . 0 0 0}$ & $\mathbf{4 . 0 0 0}$ & $\mathbf{1 . 0 0 0}$ & $\mathbf{1 7 . 0 5 1}$ \\
\hline Consistency Index (CI) \\
\hline
\end{tabular}

The CR value is 0.097 , below the critical limit of 0.1 ; therefore, the solution is consistent. The most important criterion is the Innovative development of the company (I) with the highest numerical weight (value from priority vector $=0.584$ ).

Subsequently, evaluation of the aforementioned alternatives (i.e. strategies) based on each criterion takes place.

Pairwise comparison of the alternatives by "Expansion of the customer base" according to Saaty's Rating Scale is shown in Table 3.

The highest value of the priority vector (0.381) indicates that, according to "Expansion of the customer base" criterion, the "Same products/new markets" strategy is preferred. Although the 
CBU I NTERNATI ONAL CONFERENCE ON I NNOVATION, TECHNOLOGY TRANSFER AND EDUCATION

Consistency Ratio exceeds the allowable limit, there is no significant difference, and, therefore, the solution could be considered as consistent.

\begin{tabular}{|l|c|c|c|c|c|c|c|c|}
\hline \multicolumn{1}{|c|}{ Alternatives } & $\mathbf{1}$ & $\mathbf{2}$ & $\mathbf{3}$ & $\mathbf{4}$ & $\mathbf{5}$ & $\mathbf{6}$ & $\begin{array}{c}\text { Eigenvector } \\
\text { (Priority } \\
\text { vector) }\end{array}$ & $\begin{array}{c}\text { Consistency } \\
\text { Measurement }\end{array}$ \\
\hline 1. Reverse integration & 1 & $1 / 3$ & $1 / 3$ & $1 / 4$ & $1 / 5$ & $1 / 3$ & 0.048 & 6.307 \\
\hline $\begin{array}{l}\text { 2. Development of } \\
\text { business abroad }\end{array}$ & 3 & 1 & 3 & 5 & $1 / 2$ & 7 & 0.276 & 7.457 \\
\hline 3. Direct integration & 3 & $1 / 3$ & 1 & $1 / 3$ & $1 / 5$ & 1 & 0.081 & 6.317 \\
\hline $\begin{array}{l}\text { 4. New products/same } \\
\text { markets }\end{array}$ & 4 & $1 / 5$ & 3 & 1 & $1 / 4$ & 4 & 0.147 & 6.789 \\
\hline $\begin{array}{l}\text { 5. Same products/new } \\
\text { markets }\end{array}$ & 5 & 2 & 5 & 4 & 1 & 7 & 0.381 & 6.913 \\
\hline $\begin{array}{l}\text { 6. Same products/ } \\
\text { same markets }\end{array}$ & 3 & $1 / 7$ & 1 & $1 / 4$ & $1 / 7$ & 1 & 0.067 & 6.284 \\
\hline Total & & & & & & & \\
\hline Consistency Index (CI)
\end{tabular}

Pairwise comparison of selected alternatives by "Indicators of the company's financial stability" is shown in Table 4.

Table 4: Pairwise comparison of alternatives by "Indicators of the company's financial stability" criterion

\begin{tabular}{|l|c|c|c|c|c|c|c|c|}
\hline \multicolumn{1}{|c|}{ Alternatives } & $\mathbf{1}$ & $\mathbf{2}$ & $\mathbf{3}$ & $\mathbf{4}$ & $\mathbf{5}$ & $\mathbf{6}$ & $\begin{array}{c}\text { Eigenvector } \\
\text { (Priority } \\
\text { vector) }\end{array}$ & $\begin{array}{c}\text { Consistency } \\
\text { Measurement }\end{array}$ \\
\hline 1. Reverse integration & 1 & 5 & $1 / 2$ & 3 & 3 & 2 & 0.266 & 6.583 \\
\hline $\begin{array}{l}\text { 2. Development of } \\
\text { business abroad }\end{array}$ & $1 / 5$ & 1 & $1 / 3$ & $1 / 5$ & 1 & $1 / 2$ & 0.067 & 6.434 \\
\hline 3. Direct integration & 2 & 3 & 1 & 2 & 3 & 1 & 0.259 & 6.607 \\
\hline $\begin{array}{l}\text { 4. New products/same } \\
\text { markets }\end{array}$ & $1 / 3$ & 3 & $1 / 2$ & 1 & $1 / 3$ & $1 / 3$ & 0.098 & 6.338 \\
\hline $\begin{array}{l}\text { 5. Same products/new } \\
\text { markets }\end{array}$ & $1 / 3$ & 1 & $1 / 3$ & 3 & 1 & $1 / 3$ & 0.105 & 6.736 \\
\hline $\begin{array}{l}\text { 6. Same products/ } \\
\text { same markets }\end{array}$ & $1 / 2$ & 2 & 1 & 3 & 3 & 1 & 0.204 & 6.572 \\
\hline Total & & & & & 1.000 & 39.271 \\
\hline
\end{tabular}




\begin{tabular}{|l|c|}
\hline Consistency Index (CI) & 0.109 \\
\hline Random Index (RI) for n = 6 (Saaty, 1993, p. 25) & 1.24 \\
\hline Consistency Ratio (CR) & $\mathbf{0 . 0 8 8}$ \\
\hline Source: Authors & \\
\hline
\end{tabular}

The comparison shows that the "Reverse integration" and, to a lesser extent the "Direct integration," have the greatest influence on financial stability of the company.

Similarly, pairwise comparisons of the alternatives by "Innovative Development of the Company" and "Motivation and staff development" criteria are presented in Tables 5 and 6, respectively.

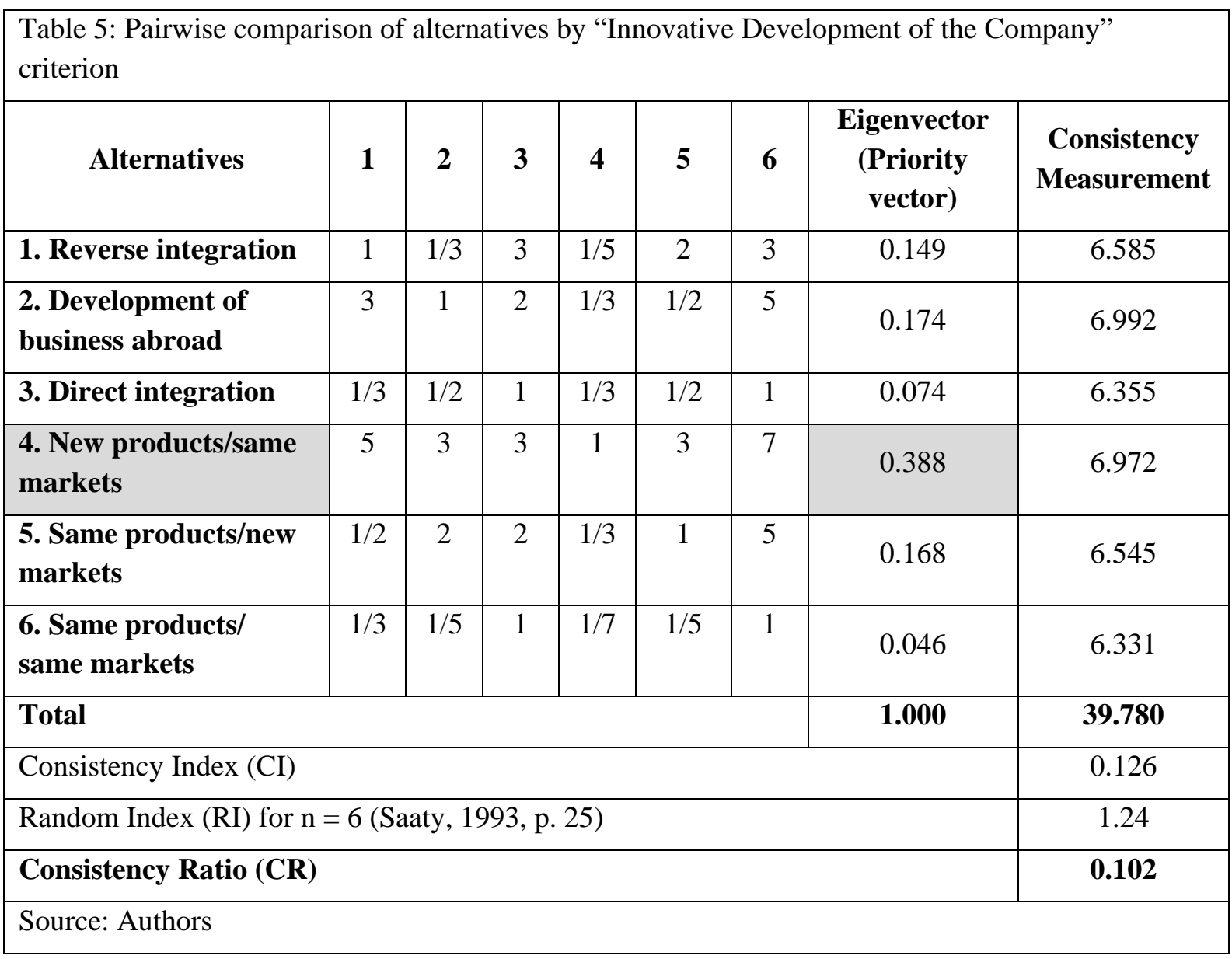

Based on the highest value of priority vector (0.388), the most appropriate strategy is "New products/same markets," which implies that the company should focus on positioning of new products in existing markets.

\begin{tabular}{|l|c|c|c|c|c|c|c|c|}
\hline \multicolumn{1}{|c|}{ Table 6: Pairwise comparison of alternatives by "Motivation and staff development” criterion } \\
\hline $\begin{array}{l}\text { Alternatives } \\
\mathbf{1}\end{array}$ & $\mathbf{2}$ & $\mathbf{3}$ & $\mathbf{4}$ & $\mathbf{5}$ & $\mathbf{6}$ & $\begin{array}{c}\text { Eigenvector } \\
\text { (Priority } \\
\text { vector) }\end{array}$ & $\begin{array}{c}\text { Consistency } \\
\text { Measurement }\end{array}$ \\
\hline $\begin{array}{l}\text { 2. Reverse integration } \\
\text { business abroad }\end{array}$ & 1 & $1 / 3$ & 2 & $1 / 3$ & $1 / 4$ & 1 & 0.082 & 6.057 \\
\hline 3. Direct integration & $1 / 2$ & $1 / 4$ & 1 & $1 / 4$ & $1 / 4$ & 1 & 0.057 & 7.083 \\
\hline
\end{tabular}


CBU I NTERNATIONAL CONFERENCE ON I NNOVATION, TECHNOLOGY TRANSFER AND EDUCATION

\begin{tabular}{|l|c|c|c|c|c|c|c|c|}
\hline $\begin{array}{l}\text { 4. New products/same } \\
\text { markets }\end{array}$ & 3 & $1 / 2$ & 4 & 1 & $1 / 4$ & 5 & 0.196 & 6.111 \\
\hline $\begin{array}{l}\text { 5. Same products/new } \\
\text { markets }\end{array}$ & 4 & $1 / 2$ & 4 & 4 & 1 & 4 & 0.289 & 7.016 \\
\hline $\begin{array}{l}\text { 6. Same products/ } \\
\text { same markets }\end{array}$ & 1 & $1 / 5$ & 1 & $1 / 5$ & $1 / 4$ & 1 & 0.060 & 6.266 \\
\hline Total & & & 1.000 & 38.812 \\
\hline Consistency Index (CI)
\end{tabular}

In this case, the "Development of business abroad" strategy is the most convenient.

\section{Results and Discussion}

Obtained values are summarized in the following matrix (Table 7). The Global priority is calculated as a weighted average of priority vectors of particular alternatives according to selected criteria. The weights correspond to eigenvector obtained from Table 2.

\begin{tabular}{|l|c|c|c|c|c|}
\hline \multicolumn{1}{|l|}{ Table 7: Determination of Global priority } \\
\hline Alternatives & E & F & I & M & Global priority \\
\hline 1. Reverse integration & 0.048 & 0.266 & 0.149 & 0.082 & 0.169 \\
\hline $\begin{array}{l}\text { 2. Development of business } \\
\text { abroad }\end{array}$ & 0.276 & 0.067 & 0.174 & 0.316 & 0.164 \\
\hline 3. Direct integration & 0.081 & 0.259 & 0.074 & 0.057 & 0.123 \\
\hline 4. New products/same markets & 0.147 & 0.098 & 0.388 & 0.196 & 0.279 \\
\hline 5. Same products/new markets & 0.381 & 0.105 & 0.168 & 0.289 & 0.174 \\
\hline 6. Same products/same markets & 0.067 & 0.204 & 0.046 & 0.060 & 0.091 \\
\hline Source: Authors & & & & \\
\hline
\end{tabular}

Calculation has shown that the "New products/same markets" is the most effective strategy for the analyzed company although "Same products/new markets," as well as "Reverse integration," is also suitable. On the other hand, the least effective is the "Same products/same markets" alternative, which corresponds to current state of the company. Only companies with the ability to innovate both products and processes can create and maintain strong competitive position.

\section{Conclusion}

The decision-making process in regard to a specific problem represents almost always a situation where the solution can be selected from several acceptable alternatives fulfilling certain conditions. However, for this set of alternatives, there is usually a whole range of views. In this case, Multiplecriteria decision-making methods could help. 
According to Saaty and Kearns, the AHP is performed by both expert and mathematical methods and divides the main problem into smaller and more detailed elements (as cited in Roháčová \& Marková, 2009, p. 105). Determining the input data as well as their comparison depends on experts' opinions, which, however, bring "human factor" into this method.

However, AHP also allows us to take into account the human factor in the preparation of decisions by creating a supplementary model for assessing different views via prioritization. This is one of the most important advantages of this method. Relative simplicity is considered as another advantage.

On the other hand, there is a fact that the selection of data necessary for further procedure in decisionmaking process is mainly carried out by pairwise comparison. This implies that the results might not be objective, and, moreover, they might contradict each other. In this case, there is a need to revise the data in order to minimize these shortcomings. However, this procedure is often time-consuming and quite laborious. This could be considered as the main disadvantage of this method. Despite this disadvantage, AHP represents a suitable tool for selecting a solution from a set of alternatives.

With the use of AHP, the most appropriate competitive strategy for BIONT, a.s. company, has been chosen. Based on the chosen strategy, the company should plan and, subsequently, execute their upcoming activities as well as adapt its investment portfolio.

\section{Acknowledgement}

This publication has been prepared as a partial output in the research project VEGA 1/0055/13.

\section{References}

BIONT, a.s. (2015a). How we work, what we do. Retrieved from http://www.biont.sk/how-we-work-what-wedo/?language $=1$

BIONT, a.s. (2015b). Company. Retrieved from http://www.biont.sk/company/?language=1

Fleisher, C. S., \& Bensoussan, B. E. (2005). Strategicheskiy i konkurentnyy analiz. Metody i sredstva konkurentnogo analiza $v$ biznese [Strategic and competitive analysis: Methods and techniques for analyzing business competition] (D. P. Kon'kova, Trans.) (I. M. Stepnov \& YU. A. Koval'chuk, Eds.). Moscow, Russia: BINOM Laboratoriya znaniy.

Kaplan, R. S., \& Norton, D. P. (2005). Balanced scorecard. Strategický systém měření výkonnosti podniku [The Balanced Scorecard. Translating strategy into action.] (4th ed.) (M. Šusta, Trans.). Prague, Czech Republic: MANAGEMENT PRESS.

Kaplan, R. S., \& Norton, D. P. (2006). Alignment - systémové vyladění organizace. Jak využít Balanced Scorecard $k$ vytváření synergii [Alignment. using the Balanced Scorecard to create corporate synergies] (I. Grusová, Trans.). Prague, Czech Republic: MANAGEMENT PRESS.

Porter, M. (2005). Konkurentnaya strategiya: Metodika analiza otrasley i konkurentov [Competitive strategy: Techniques for analyzing industries and competitors] (I. Minervin, Trans.) (O. Nizhel'skaya, Ed.). Moscow, Russia: Al'pina Biznes Buks.

Roháčová, I. \& Marková Z. (2009). Analýza metódy AHP a jej potenciálne využitie v logistike. Acta Montanistica Slovaca, 14, 103-112. Retrieved from http://actamont.tuke.sk/pdf/2009/n1/15rohacova.pdf

Saaty. T. (1993). Prinyatiye resheniy. Metod analiza iyerarkhiy [Decision making. Analytic hierarchy process] (R. G. Vachnadze, Trans.). Moscow, Russia: Radio i svyaz'. 